Ewa Boksa

DOI: $10.33896 /$ PorJ.2021.1.2

(Uniwersytet Jana Kochanowskiego, Kielce,

e-mail: eboksa@ujk.edu.pl)

ORCID: 0000-0003-3041-82-83

\title{
PRZYIMEK I JEGO UŻYCIE W PRACACH PISEMNYCH OSÓB DYSLEKTYCZNYCH
}

\section{WPROWADZENIE}

Ostatnie lata przyniosły wzrost zainteresowań językoznawców pisana wersja języka u osób $z$ dysleksja rozwojową. Przyjmując językowy mechanizm dysleksji rozwojowej, należy założyć, że u dzieci w różnym wieku, o słabych umiejętnościach w zakresie czytania i pisania, istnieja deficyty w zakresie świadomości językowej, szybkiego nazywania, umiejętności syntaktycznych i morfologicznych, przetwarzania i konstruowania wypowiedzi słownych i pisemnych [Krasowicz-Kupis 2004; 2008; 2009; Makarewicz 2006; Boksa 2019]. Stąd w wypowiedziach pisemnych i mówionych osób dyslektycznych obserwuje się nagromadzenie błędów semantycznych i składniowych. Wpływa to niekorzystnie na dekodowanie (identyfikację) słów, uniemożliwiając ich rozpoznanie, co z kolei powstrzymuje dostęp do procesów językowych wyższego rzędu, a więc odkrywania znaczenia $z$ tekstu lub budowania własnej narracji [Boksa 2019]. Cel rozważań w niniejszej pracy stanowi pytanie, czy osoby dyslektyczne, u których przed podjęciem nauki szkolnej stwierdzono opóźniony rozwój mowy, poprawnie stosuja przyimki w wypowiedziach pisemnych i jak umiejętność operowania wyrażeniami przyimkowymi wpływa u nich na tworzenie struktur zdaniowych. Analizy wypracowań uczniów dyslektycznych potwierdziły, że jednym $z$ podstawowych wskaźników ujawnienia się dysleksji rozwojowej może być czas akwizycji przyimka, rozumienia i stosowania tej części mowy w wypowiedziach ustnych i pisemnych.

\section{DYSLEKSJA ROZWOJOWA}

Dysleksja to zaburzenie kompetencji językowej oraz komunikacyjnej przejawiajace się w nieumiejętnym budowaniu dyskursu rozumianego jako strumień mówionych lub pisanych zachowań językowych [Boksa 2019, 67]. Taka definicja zarysowuje obszar badań diagnostycznych 
i terapeutycznych w edukacji polonistycznej, logopedycznej, językowej. $\mathrm{W}$ prowadzonych ostatnimi laty analizach na temat przyczyn dysleksji szczególne miejsce zajmuje świadomość metajęzykowa [Maurer 1997; Krasowicz-Kupis 2004]. Jest to zdolność uzmysłowienia sobie znaczenia takich aspektów językowych jak: morfologiczny (rozpoznawanie morfemów, czyli najmniejszych znaczeniowych cząstek języka), syntaktyczny (rozpoznawanie i używanie zasad gramatycznych służących do budowania zdań), semantyczny (wyrażanie myśli, rozumienie znaczeń). Pojawia się ona w momencie, gdy dziecko odkrywa istnienie zdania jako formy służącej do zwerbalizowania myśli. Jedna $z$ wczesnych oznak pojawienia się świadomości fonologicznej u dziecka jest spontaniczne poprawianie własnych wypowiedzi. Zdolność ta jest przez wielu autorów uznawana za wstępny warunek opanowania umiejętności czytania i pisania [por. A. Maurer 1997]. Próby badania kompetencji językowej i jej realizacji na innych niż fonologiczny poziomach organizacji języka wykazały jednak, że jednym ze wskaźników ujawnienia się dysleksji może być czas wystąpienia przyimka w rozwoju mowy oraz stosowania przyimka w zdaniu i rozumienia jego znaczenia w procesie komunikacji [Boksa 2019; Zarębina 1994, 107-137].

\section{ETAPY ROZWOJU SYSTEMU ZNACZENIOWEGO}

W rozwoju mowy dziecka można zatem wyróżnić trzy stadia rozwojowe systemu znaczeniowego [Zarębina 1994; Porayski-Pomsta 2007]. W pierwszym stadium, przypadającym na okres między 9./12. a 18./24. miesiącem życia dziecka, formuje się pierwsza sfera słownikowa, która tworzą: wykrzykniki, które w tym okresie odgrywaja znaczna rolę w mowie dzieci (np. bah, be, sisi, hau-hau); wyrazy nazywajace, przede wszystkim rzeczowniki (np. mama, tata, baba, ciocia, wujek, kicia, hauhau, buzia, kolanko, bucie), następnie czasowniki (np. daj, ma, pa); wyrazy nazywające: przymiotniki (np. caca 'ladny', be 'brzydki') i przysłówki, również śladowo pojawiają się wyrazy wskazujące - zaimki. Obserwując rozwój mowy dziecka w tym okresie, trudno jest określić jednoznacznie znaczenie wyrazu; większość wyrazów jest wieloznaczna, część ma charakter dźwiękonaśladowczy [Porayski-Pomsta 2007].

W drugim stadium rozwojowym, które przypada na okres między 24. a 36. miesiącem życia, następuje gwałtowny przyrost słownictwa - średnio do około pięciuset-tysiąca wyrazów [Porayski-Pomsta 2007]. Zmienia się struktura słownika. Na pierwszym miejscu znajdują się rzeczowniki, które zajmuja niewiele ponad 50\% całego zasobu leksykalnego. Na drugim - czasowniki, które stanowią blisko 25\% słownika, na trzecim - wykrzykniki, około 5\%, również około 5\% słownika stanowią przymiotniki, dalej - przysłówki, około 3\%, zaimki, również około 3\%. W tym etapie rozwojowym pojawia się nowa warstwa leksykalna: wyrazy szeregujące, 
czyli liczebniki, które stanowią około $2 \%$ wszystkich wyrazów, i tzw. morfemy luźne, czyli inaczej wyrazy gramatyczne: przyimki (nieco ponad 1\% słownika) i spójniki (około $0,5 \%$ ) oraz wyrazy modyfikujące znaczenie wyrazów nazywających - partykuły (około 0,5\%). Struktura słownika dziecka zbliża się do struktury słownika dorosłego użytkownika języka. Zanikaja wyrazy wieloznaczne, znamienne dla poprzedniej fazy rozwojowej. Istotna właściwością drugiego stadium jest - w związku $z$ rozwojem składni - pojawienie się wyrazów gramatycznych: przyimków i spójników oraz wzrost liczby zaimków względnych, które służą łączeniu zdań złożonych.

W trzecim stadium rozwojowym zwanym okresem swoistej mowy dziecka (4-7 lat) kształtuje się warstwa słownikowa, która charakteryzuje umocnienie i ustalenie funkcji wyrazów $z$ drugiego stadium rozwojowego, a więc wyrazów szeregujących, liczebników oraz wyrazów gramatycznych: przyimków i spójników. Dzieci coraz lepiej rozumieją znaczenie wyrazów porządkujących; wiąże się to ze wzrostem umiejętności liczenia i porządkowania obiektów, co jest wyraźnym wynikiem działań edukacyjnych otoczenia. Wzrasta także rozumienie użycia wyrazów gramatycznych: przyimków i spójników. Należy tu zwrócić uwage na istotna funkcje przyimka, która wpływa na kształtowanie kompetencji językowej przez to, że wyznacza relacje między składnikami wypowiedzenia, ustala rzad przypadkowy [Grochowalski 1997, 16-17].

Jak widać, przyimek pojawia się w drugim etapie rozwoju mowy dziecka, kiedy kształtuja się kompetencje składniowe. Wtedy też w mowie dziecka możemy wyróżnić zdanie oraz inne wyrażenia funkcjonalno-syntaktyczne, np. wyrażenia przyimkowe. Opóźnienie rozumienia znaczenia przyimka w zdaniu widoczne jest podczas badań przesiewowych dotyczących oceny rozwoju mowy [Tarkowski 1992; Grabias, Kukowski, Woźniak 2007; Emiluta-Rozya, Smoczyńska, Haman i współp. 2015]. Warto więc zwrócić uwagę, że rozumienie przyimków przez dziecko i ich stosowanie w mowie czynnej potwierdza przyrost kompetencji językowej, tym samym prowadzi do wykształcenia się i utrwalenia w umyśle dziecka odrębnych grup wyrazów o specyficznych właściwościach semantycznych, służących do podejmowania różnorodnych funkcji komunikacyjnych, między innymi tekstotwórczych. W zwiazku z powyższym konieczne jest poczynienie kilku uwag na temat przyimka.

\section{ROLA PRZYIMKA W ZDANIU}

Przyimek (łac. praepositio) - w ujęciu tradycyjnym to nieodmienna i niesamodzielna część mowy, która łączy się z innymi wyrazami i nadaje im określony sens. Na przykład rzeczownik stół tworzy z przyimkami wiele zestawień: na stole, o stole, za stołem, obok stoku, po stole, pod stołem, zza stołu, koło stołu, przy stole, ponad stołem, od stołu, ku stołowi 
itp. Przyimki $w, z$, ze w połaczeniu $z$ rzeczownikiem, przymiotnikiem lub liczebnikiem tworza wyrażenia przyimkowe, np. z nudów, ze strachu, sklep $z$ butami, zeszyt $w$ kratkę, $z$ piętnaście, ze sto, $z$ milion [Zgółkowa 1980, 17]. Wyjaśnienie powyższej definicji tłumaczy się funkcją syntaktyczna przyimków w związkach wyrazowych.

We współczesnych pracach językoznawczych przyimek traktowany jest przede wszystkim jako jednostka leksykalna, choć rzeczywiście nie spełnia wszystkich warunków wyrazu tekstowego. Nie tworzy bowiem samodzielnie wypowiedzenia, nie może zmienić pozycji względem rzeczownika w wyrażeniu przyimkowym. Ma jednak pewne cechy, które pozwalają uznać go za leksem. Do nich należy przede wszystkim możliwość wstawienia przymiotnika (zaimka) między nim a rządzonym rzeczownikiem [Janowska 2015, 16].

Drugie stanowisko wiąże przyimek $z$ morfemem, stojącym przed forma przypadkowa wyrazu, z którego końcówka postulowana przez siebie tworzy całość określająca funkcje gramatyczne danego wyrazu w zdaniu [Gołąb, Heinz, Polański 1968, 452; Janowska 2015, 15]. Również Tadeusz Milewski [2005, 84-86] zwraca uwagę na powyższe właściwości przyimka. Jerzy Kuryłowicz podaje natomiast, że przyimek wraz z końcówka przypadka stanowi funkcjonalna jednostkę języka jako samodzielny morfem nieciagły [por. Kuryłowicz 1949; Zgółkowa 1980, 17-19; Polański 1993, 432; Buttler, Kurkowska, Satkiewicz 1973, 35; Klebanowska 1971, 5].

Przyimki stanowią więc klasę otwartą, uzupełnianą przez wyrazy samodzielne, i funkcjonuja jako wykładniki stosunków semantyczno-syntaktycznych. Przyimek związany jest bowiem $z$ faktami, o których mowa, odsyła nas do nich i łączy na oznaczanej przez siebie zasadzie: moga to być relacje przyczynowo-skutkowe, celowe, warunkowe, lokatywne, temporalne itp. badź też relacje oparte na prostym zestawieniu faktów.

Hanna Jadacka [2008, 213] wyróżnia dwie podstawowe funkcje przyimka: wskazywanie związków składniowych między wyrazami samodzielnymi semantycznie (np. kiosk przy dworcu); sygnalizowanie typu relacji między desygnatami wyrazów samodzielnych znaczeniowo. W konsekwencji przyimki wyróżniają się sprecyzowana semantyka, wyznaczaniem dość konkretnych relacji między składnikami zdania [Janowska $2015,20]$, tym samym pomagaja porządkować logicznie bieg wydarzeń i znaczenie wypowiedzi.

\section{BADANIA WLASNE}

Materiał stanowiący podstawę badań funkcji syntaktycznych przyimków i wyrażeń przyimkowych został wyekscerpowany z protokołów badania rozwoju mowy dzieci sześcioletnich oraz opowiadań tworzonych przez te same osoby wiele lat później, będących uczniami ósmej klasy szkoły 
podstawowej. Dane zostały zgromadzone we wrześniu 2010 i 2018 r. i obejmowały:

a. z 2010 r. 10 protokołów z badań przesiewowych dotyczących rozwoju mowy uczniów przed rozpoczęciem nauki szkolnej;

b. z 2018 r. 10 tekstów napisanych przez tych samych uczniów, którzy osiem lat wcześniej, w wieku sześciu lat, w związku z opóźnionym rozwojem mowy, uczestniczyli w terapii logopedycznej; analiza zdań użytych w wypracowaniach tych uczniów pozwoliła na uchwycenie sposobów użycia przyimków w tekstach przez nich tworzonych oraz ustalenie, czy ci uczniowie, majaccy już na etapie klasy ósmej szkoły podstawowej zdiagnozowane trudności w czytaniu i pisaniu, zdolni sa do tworzenia struktur właściwych szerszym kontekstom narracyjnym. W pierwszym etapie w 2010 r. podczas badania logopedycznego wykorzystano Logopedyczny test przesiewowy dla dzieci w wieku szkolnym [Grabias, Kurkowski, Woźniak 2007]; w drugim etapie badania w 2018 r. zastosowano obserwację oraz analizę językoznawczą uczniowskich wypracowań.

\section{OMÓWIENIE WYNIKÓW BADAŃ I DYSKUSJA}

Zgodnie $z$ funkcjonującym obecnie w Polsce systemem edukacji obowiązkowy czas nauki w przedszkolu, a później w szkole podstawowej, przypada na okres między piatym a czternastym rokiem życia. Powszechnie przyjmuje się, że mowa dzieci siedmioletnich jest już w pełni ukształtowana. Wypowiedzi powinny być poprawne pod względem fonetycznym, a dziecko mieć w swoim słowniku kilka tysięcy wyrazów i stosownie do sytuacji budować zdania prawidłowe pod względem składniowym. Wyniki badania w pierwszym etapie wykazały, że uczniowie, mający wtedy sześć lat, uzyskali w przesiewowym teście logopedycznym od 23 do 36 punktów, czyli poniżej normy. Norma obejmowała przedział od 37 do 66 punktów. Na gorszy wynik wpłynął mały zasób słownictwa, obniżona percepcja dźwięków mowy oraz problemy $z$ budowaniem narracji. Uczniowie ci uczęszczali na terapię logopedyczna, następnie terapię pedagogiczna, ponieważ w pierwszej klasie szkoły podstawowej pojawiły się u nich problemy związane $z$ nauka czytania. Do końca trzeciej klasy szkoły podstawowej, dzięki systematycznej terapii, poszerzyli zasób słownictwa, poprawili umiejętność czytania, jednakże ujawniły się u nich kłopoty $z$ pisownia, dotyczyły budowania dłuższych tekstów (opowiadań), stosowania regul ortograficznych $\mathrm{w}$ praktyce oraz tworzenia poprawnych struktur morfologicznych i syntaktycznych języka.

Drugi etap badania dotyczył już analizy procesów zdaniotwórczych w wypowiedziach pisemnych wyżej wymienionych uczniów. Przede wszystkim ujawniły się tu nieprawidłowo funkcjonujące procesy akomodacji morfologicznej (błędy w budowaniu związków składniowych). 
Dokonując analizy składniowej opowiadań napisanych przez badanych, należy stwierdzić, że syntaktyczna płaszczyzna ich wypowiedzi narracyjnych jest nieróżnorodna i mniej skomplikowana, co łączy się z uboższą semantycznie strona opowieści. Tor składniowy tekstów dzieci dyslektycznych został naruszony w wyniku skracania treści opowiadania. Potwierdza to zastosowanie mniejszej liczby słów i zdań w opowiadaniu. Ocena rozmiarów opowiadań pozwala stwierdzić, że dzieci z dysleksja budują teksty ze zdań istotnie krótszych. Analizując warstwę składniową opowiadań tworzonych przez uczniów dyslektycznych, można dostrzec również tendencję do niekończenia rozpoczętych zdań. Błędy tego rodzaju pojawiaja się głównie w zdaniach złożonych podrzędnie lub wielokrotnie złożonych. W tego rodzaju wypowiedziach orzeka się bowiem o przyczynie i skutku danej czynności. Uczniowie dyslektyczni w pracach pisemnych używaja mniejszej liczby zdań złożonych. W pracach pisemnych dzieci dyslektycznych występuje większa liczba zdań złożonych współrzędnie w stosunku do zdań złożonych podrzędnie. Sugeruje to kłopoty $z$ odtworzeniem przyczynowo-skutkowego biegu wydarzeń. Dzieci dyslektyczne również niepoprawnie stosują reguły gramatyczne, czyli niewłaściwie dobierają formy (zgody, rządu lub przynależności) wyrazu podrzędnego do nadrzędnego, błędnie odmieniają niektóre wyrazy, używaja jednego rzeczownika w funkcji dopełnienia dwóch czasowników [Boksa 2019, 97]. Błędy w użyciu przyimków klasyfikuje się również jako błędy gramatyczne [Cegieła, Markowski 1982; Markowski 1999). Można wyodrębnić ich następujące kategorie:

- nieprawidłowy wybór przyimka: Wtedy olbrzym zobaczył dzieci siedzace na ogrodzie. Dla takiego podejścia, przewidujemy.... Olbrzym nie lubił ludzi dla najróżniejszych powodów. Dzięki chorobie nie pojawit sie w ogrodzie;

- nieprawidłowa rekcję: Podobny olbrzymem był ten ogród. Nie nadawat się na konspirację. Dzieci kupiły wszystko dla ogrodu;

- niepoprawne użycie przyimka w wyrażeniach, w których według normy językowej przyimek nie występuje: Chłopiec napotykał $w$ tym ogrodzie na różne przeszkody. Daj buzi dla mamy. Student z fizyki widział to wszystko. Piszę z ołówkiem. Nastapiło u dzieci zrozumienie dla zadań.

Ponadto ze względu na funkcje przyimka pojawiły się błędy, które dotyczyły [por. Żeberek 1994, 39-40]:

\section{I. oznaczania deiktyczności i anafory:}

Dzieci na tym bajkowym ogrodzie zdawały sobie sprawę $z$ tego, jak bardzo sa szczęśliwe.

Podczas siedmiu lat nieobecności wrócił olbrzym.

Mieszkat tam, na lewo dworu.

Za lasu wynurzył się olbrzym.

Dom stak na boku drogi. 
Stanie sie to $w$ kilka dni.

Na przestrzeni dziesięciu lat ogród stał pusty.

Jak widać, uczniowie dyslektyczni stosuja przyimki wyrażające zależności lokatywne i temporalne $z$ zamierzeniem odesłania do wypowiedzi (do samego aktu mowy, czasu i przestrzeni mówiącego bądź obserwatora, wydzielanego tam, gdzie osoba mówiącego nie jest wyrażana), albo do czasu i miejsca innych, przedstawianych w wypowiedzi zdarzeń, a więc rozumieja funkcję deiktyczna lub anaforyczna przyimka, ale wątpliwości budzą błędy gramatyczne w budowanych zdaniach.

\section{II. szeregowania faktów:}

Mimo wszystkiego złego olbrzym sie poprawit.

Nie mówiąc o złych ludziach w porównaniu do nich olbrzym byt niedobry. Obok zwierzat, dzieci i ich samych wszyscy przyszli.

Funkcję szeregowania faktów przypisujemy przyimkom zawierającym odesłania do zdarzeń porównywalnych, występujących $z$ wykładnikami konkatenacji, czyli tworzenia szeregu. Pozostaja one w bliskich związkach semantycznych ze spójnikami, łączącymi zdania współrzędne. Łatwo przyjmują one funkcję spójników. Zaliczymy do nich: oprócz, mimo, pomimo, obok, nie mówiąc o, $w$ porównaniu $z, w$ odróżnieniu od, $w$ przeciwieństwie do, bez względu na zamiast $z$ wyjątkiem itp. Również i w tym aspekcie widać zaburzona kompetencje składniowa oraz znaczeniowa. Przyimki nie odpowiadają kontekstowi zdania.

\section{III. przylegania faktów:}

W związku z nieobecnościa olbrzyma dzieci się nie bały.

Ten przykład wskazuje na niezrozumienie funkcji właściwej przyimkom zawierającym odesłania do dwóch faktów, które mogą być dobierane dowolnie i łączone na zasadzie asocjacji semantycznych. Żadne wymogi w stosunku do nich nie sa przez takie przyimki narzucane, ale pewna rolę w porządkowaniu wypowiedzi odgrywa kolejność podawania faktów. Wyrazy, o jakich tu mowa, łatwo przyjmuja funkcję spójników, łącząc zdania na tej samej zasadzie, tworzą też wykładniki spójności międzyzdaniowej. Takie właściwości ma niewielka grupa wyrazów: $w$ związku $z, w$ zależności od.

\footnotetext{
IV. łączenia faktów na zasadzie: przyczyna - skutek, działanie - cel, rezultat działania, efekt - warunek jego uzyskania itp.:

Dziewczynka przyszła chętnie $w$ celu pomocy.

Zwyciężyt pod warunkiem szczęścia.

$W$ rezultacie olbrzyma, wszyscy się bali.
} 
Niewłaściwie użyty przyimek tego typu powoduje niejednoznaczne interpretacje, zmusza odbiorcę wypowiedzi do ciagłego odwoływania się do kontekstu, wpływa na rozumienie treści.

Przy omawianiu przyimków zwracają więc uwage zjawiska, które moga wskazywać nie tylko na ich właściwości składniowe, tekstotwórcze, ale i znaczeniowe. Pierwsze $z$ nich dotyczy semantyki przyimków, zawierających takie odesłania do faktów, które pozwalają na ich porządkowanie np. poprzez szeregowanie, włączanie do szeregów, wyłączanie z szeregów, co może służyć uzyskiwaniu spójności semantycznej tekstu. Drugie zjawisko dotyczy potwierdzonej badaniami statystycznymi tendencji do umieszczania połączeń przyimkowych na granicy zdania. Również i tu w uczniowskich wypracowaniach pojawiły się błędy:

Olbrzym się rozczulit, przy czym był bardzo smutny i zły cały czas. Toteż dzieci się bały.

Jak widać w przytoczonych przykładach, wybór i realizacja gramatyczna przyimka daje się analizować w kategoriach budowania związków semantycznych na gruncie odniesień formalnych w tekstach. Można założyć, że w wieku 10-14 lat mowa dziecka osiaga pełną dojrzałość składniowa, zarówno w rozumieniu, jak i budowaniu wypowiedzi [Grabias, Kurkowski, Woźniak 2007, 19], a błędy, które popełniają uczniowie w tym przedziale wiekowym nie różnią się od błędów dorosłych użytkowników języka, jednakże u uczniów dyslektycznych zwracają uwagę odstępstwa w zakresie budowania wyrażeń przyimkowych. Na ten rodzaj błędów wskazywała też Renata Makarewicz [2007, 81]. Status niewłaściwie zastosowanego przyimka czy wyrażenia przyimkowego stosowanego przez osoby dyslektyczne stanowi istotny wskaźnik zaburzeń kompetencji składniowej, ale też potwierdza, że dysleksja rozwojowa jest zaburzeniem językowym. Trzeba jednak podkreślić, że już w tradycyjnych gramatykach formułowane są definicje zawierające ze współczesnego punktu widzenia podstawowe cechy przyimków. I tak przykładowo, w opracowaniu Stanisława Szobera [1959, 103-104], stosujaccego semantyczną wykładnię klasyfikacyjną, odnaleźć można adnotację o tym, że:

przyimki sa wyrazami niesamodzielnymi, które łączą niejednorodne części zdania lub wyrażenia, określaja przeto związki podrzędne zachodzące między wyrazami samodzielnymi. Ich cechą formalną jest to, że w odróżnieniu od spójników rządzą one przypadkami zależnych od nich wyrazów [Janowska 2015, 17].

Nieprawidłowe zastosowanie reguł gramatycznych, w które wpisany jest przyimek, zaburza spójność tekstu, relacje zachodzące w ramach linearnej sekwencji wyrazów w obrębie zdania oraz zdań w obrębie akapitu, tym samym może wpływać na znaczenie tekstu. Dzięki zastosowaniu przyimka możemy ustalić hierarchię ważności informacji w zdaniu, 
ustalić współzależność między elementami świata przedstawionego. Na zakończenie tych krótkich rozważań przytoczę zdanie Joanny Okoń [1987, 9], przekonanej, że nie da się opisywać przyimków bez odniesienia do ich znaczenia:

Mimo różnicy stanowisk badawczych obie podgrupy nakładają się częściowo, dlatego stanowia jedna, choć zróżnicowaną całość. Nawet gdy punktem wyjścia jest funkcja gramatyczna przyimka, to i tak w końcu dochodzi się do jego znaczenia.

\section{Bibliografia}

E. Boksa, 2019, Systemowy trening językowy - STJ-dysleksja. O rozwijaniu kompetencji komunikacyjnej uczniów dyslektycznych $w$ starszych klasach szkoły podstawowej $w$ ramach edukacji polonistycznej, Kielce.

D. Buttler, H. Kurkowska, H. Satkiewicz, 1986, Kultura języka polskiego. Zagadnienia poprawności gramatycznej, Warszawa.

A. Cegieła, A. Markowski, 1982, Z polszczyzna za pan brat, Warszawa.

Z. Gołąb, A. Heinz, K. Polański, 1968, Słownik terminologii językoznawczej, Warszawa.

S. Grabias, Z. Kurkowski, T. Woźniak, 2007, Logopedyczny test przesiewowy dla dzieci $w$ wieku szkolnym, Lublin.

H. Jadacka, 2008, Kultura języka polskiego. Fleksja, słowotwórstwo, składnia, Warszawa.

A. Janowska, 2015, Kształtowanie się klasy polskich przyimków wtórnych, Katowice.

B. Klebanowska, 1971, Znaczenie lokatywne polskich przyimków właściwych, Wrocław-Warszawa.

G. Krasowicz-Kupis, 2004, Rozwój świadomości językowej dziecka. Teoria i praktyka, Lublin.

G. Krasowicz-Kupis, 2008, Świadomość językowa a komunikowanie się za pomoca pisma [w:] M. Bogdanowicz, M. Lipowska (red.), Rodzinne, edukacyjne i psychologiczne wyznaczniki rozwoju, Kraków, s. 159-166.

G. Krasowicz-Kupis, 2009, Badanie funkcji językowych w dysleksji [w:] G. Krasowicz-Kupis (red.), Diagnoza dysleksji, najważniejsze problemy, Gdańsk, s. $188-202$.

R. Makarewicz, 2006, Dysleksja w opinii językoznawcy. Składnia zdania w wypowiedziach pisemnych uczniów dyslektycznych, Olsztyn.

A. Markowski, 1999, Nowy słownik poprawnej polszczyzny, Warszawa.

A. Maurer, 1997, Program kształtowania świadomości fonologicznej dla dzieci przedszkolnych i szkolnych, Kraków.

T. Milewski, 2005, Językoznawstwo, Warszawa.

J. Okoniowa, 1987, Polskie przyimki gwarowe: znaczenie przestrzenne i czasowe, Wrocław.

J. Porayski-Pomsta, 2007, O czynnikach wpływajacych na opanowywanie przez dziecko znaczeń, http://www.tkj.uw.edu.pl/poradnia/art05.htm

D. Emiluta-Rozya, 2013, Całościowe badanie logopedyczne, Warszawa. 
M. Smoczyńska, G. Krajewski, M. Łuniewska, E. Haman, K. Bulkowski, M. Kochańska, 2015, Inwentarze rozwoju mowy i komunikacji (IRMIK): SEOWA I GESTY, SŁOWA I ZDANIA. Podręcznik, Warszawa.

S. Szober, 1957, Gramatyka języka polskiego, Warszawa.

S. Szuman, 1968, Rozwój treści słownika dzieci [w:] S. Szuman (red.), O rozwoju języka i myślenia dziecka, Warszawa, s. 19-95.

Z. Tarkowski, 1992, Test sprawności językowych, Lublin.

M. Zarębina, 1994, Rozwój semantyczny języka dziecka i opanowywanie przez nie wyrazów z funkcja gramatyczna [w:] Język polski w rozwoju jednostki. Analiza tekstów dzieci. Rozwój semantyczny. Dyskusja nad teoria Chomskiego, Gdańsk, s. 107-137.

H. Zgółkowa, 1980, Funkcje syntaktyczne przyimków i wyrażeń przyimkowych we współczesnej polszczyźnie mówionej, Poznań.

T. Żeberek, 1994, Funkcjonowanie przyimków i wyrażeń przyimkowych $w$ tekście rosyjskim i polskim, Kraków.

\section{The preposition and its use in essays of dyslexic students}

\section{Summary}

The research presented in this paper is aimed to answer the question whether dyslexic people who had been diagnosed with delayed speech development before they started school use prepositions correctly in statements and how their ability to use prepositional phrases affects their formation of sentence structures. The material underlying the research on the syntactic functions of prepositions and prepositional phrases has been extracted from reports on speech development for six-year-old children and stories created by the same people many years later, when they were eighth-year students. Analyses of dyslexic students' essays have confirmed that one of the key indicators of developmental dyslexia, which is helpful in diagnosis, could be the preposition acquisition time as well as understanding and using this part of speech in utterances and statements.

Keywords: preposition - developmental dyslexia - delayed speech development

Adj. Monika Czarnecka 